\title{
A Survey on the Health and Financial Status of Private Educational Institutions in Afghanistan During COVID-19 Pandemic
}

\author{
Arash Nemat ${ }^{1,2}$ \\ Nahid Raufi (iD ${ }^{3}$ \\ Mohammad Yasir Essar ${ }^{4}$ \\ Qingchun Zeng ${ }^{2}$ \\ 'Department of Microbiology, Kabul \\ University of Medical Sciences, Kabul, \\ Afghanistan; ${ }^{2}$ Department of Cardiology, \\ Nanfang Hospital, Southern Medical \\ University, Guangzhou, 5105I5, People's \\ Republic of China; ${ }^{3}$ Department of \\ Dermatology, Kabul University of Medical \\ Sciences, Kabul, Afghanistan; ${ }^{4}$ Medical \\ Research Center, Kateb University, \\ Kabul, Afghanistan
}

Purpose: The worldwide spread of the coronavirus named SARS-CoV-2 has disrupted the world economy and the economy of Afghanistan as part of it. In addition, it has affected health and education in the country. The aim of this study is to highlight the damage the pandemic has done to private educational institutes in Afghanistan, in terms of finances, health and educational aspects. This is to draw attention to the setbacks the COVID-19 pandemic has caused to post-war (ie, post 2001) Afghan private education.

Methods: A cross-sectional study was conducted with the help of Afghanistan's Educational Centers Association (AECA) members to analyze the impact of the COVID-19-related lockdown. The questionnaire for the survey was distributed through SurveyMonkey to founders of educational institutes. It included basic demographics, perception of and exposure to COVID-19 by the participants and the educational and financial state of their institutions. Data analysis was conducted using SPSS software version 25.

Results: Almost all participants who completed the questionnaire were male; $82 \%$ of them were under 35 years old, the others were older. Fifty-one percent obtained their COVID-19related information through social media. Fifty-six percent confirmed that either they themselves or employees had tested positive with COVID-19. Eighty-seven percent of their educational institutes were not conducting any online classes. Only $2 \%$ received continued payment from their students. Five percent did not pay rent for their center's lease. Regarding the economic damage during the lockdown period (March to July 2020) they encountered, $47 \%$ reported a loss of $2000-5000 \$$ with a decreasing amount of participants responding and an ascending amount of financial loss.

Conclusion: COVID-19 pandemic caused a significant financial and educational loss to the private educational institutes in Afghanistan. The lockdown induced by it affected students' fees transactions, induction of online classes, substantial financial loss, and it elevated the health crisis according to the founders of private educational institutes' reports.

Keywords: learning center, coronavirus, education crisis, survey, school, student

\section{Introduction}

\section{Background}

Education plays an important role to set economic, social and moral values of any nation and it has a rather lasting effect on ideas and beliefs regarding future strategies for any country. ${ }^{1}$ Afghanistan that is located in Central Asia and can be proud of the bright history of its education. 1400 years ago, after the rise of Islam in Afghanistan, the emphasis on religious education resulted in the simultaneous growth of science and
Department of Microbiology, Kabul University of Medical Sciences, 3rd District, Jamal Mina, Kabul, I00I, Afghanistan

Tel +93706717987

Email dr.arashnemat@yahoo.com 
scientific education. ${ }^{2}$ Presently, the Afghan government education system consist of primary and secondary school education (16,500 public schools with over 8 million students, $16 \%$ of whom are female), ${ }^{3,4}$ religious education in mosques (mostly informal), vocational training in institutions, and higher education in universities. ${ }^{5}$ To get free education up to bachelor's level is a constitutional right for every child in Afghanistan. ${ }^{6}$ Similarly, after basic general education students are entitled to complete free specialized vocational and technical education in specific institutions. However, due to the limited capacity of governmental universities and institutions of higher learning, the graduate students must pass the national admission test (Kankor exam) to enroll there. ${ }^{7}$ Additionally, students who want to apply for scholarships or find jobs within the country (especially in international organizations) need to master English. ${ }^{8}$ Although from the fourth grade onward English is a compulsory subject for all students, it is supposed to being offered to them in universities for at least four semesters. ${ }^{9}$ But due to lack of professional tutors this is not the case and interested students who can afford it study English in private educational centers. Most private learning centers have been established because of this. ${ }^{5,10}$

Private educational institutions by definition, have been established by individuals. Therefore, they do not have government support and struggle with unexpected incidents such as pandemics, because of their rather minimal infrastructure and facilities (eg internet), poor external funding, taxes and many more. ${ }^{11}$

\section{COVID-19 and Education in Afghanistan}

In Afghanistan, after the emergence of the COVID-19 pandemic in March 2020, the challenges encountered by private educational institutions plummeted significantly. All educational institutions had to halt their operations due to the rules of lockdown. This affected their financial and functional outcomes. Many students were unable to pay fees, hence, the institutions could no longer pay the rent for buildings and the teachers' salaries. ${ }^{12}$ This resulted in the present discontinuation of all education programs. In most cases online learning was not an option, because schools and students could not afford the installations necessary. In addition, teachers and students were not able to provide/follow online education because of lacking technical preparation. ${ }^{13}$

Along with educational issues, the health concerns during the pandemic was extremely severe as $31.5 \%$ of the Afghan population were infected with COVID-19 in June $2020 .{ }^{14}$ During the first wave, educational institutions were closed temporarily. Nevertheless it did not take long for the second wave of COVID-19 to start. Many students tested positive, forcing the government to close down schools again. ${ }^{15}$ Rising health concerns prevented children from pursuing their education, which may have a negative long-term impact. ${ }^{16}$ As, the infection rates were high all education centers, schools and universities remained closed for an extended period of time.

\section{Objectives}

With the many problems encountered by all educational institutions in Afghanistan, a few professors from Kabul University of Medical Sciences decided to conduct a survey to effectively evaluate the first-hand problems faced by them by going directly to the source, the owners of private universities and schools. The questionnaire was distributed in order for the researchers to learn about the particular challenges private educational institutions are facing during COVID-19 by their owners. The results of the survey in terms of institutes that were doing well during the pandemic were very poor. The owners declared a state of crisis at their institute concerning finances as well as students and staff. The health crisis was emerging amongst their employees as most were exposed to the SARS-CoV-2 virus.

This research is to determine the financial losses experienced by private educational institutes and to highlight the lack of government investment in them. This research is to raise awareness of the COVID-19 setbacks that disrupted the recent progress and achievements of the education system in Afghanistan.

\section{Materials and Methods}

\section{Study Participants and Survey Design}

On August 2020, a cross sectional web-based anonymous survey using an online questionnaire was conducted with the help of the members of the Afghanistan's Educational Centers Association (AECA), that represents the private educational institutions, in order to analyze the impact of the COVID-19 lockdown period on educational centers. The survey was conducted through the SurveyMonkey website and took approximately two minutes to complete. The inclusion criteria were that the respondents were Afghan residents who were founders of private educational institutions in Afghanistan aged between 18 and 70 years. The questionnaire was developed in English and was then translated into Dari, one of the national languages of Afghanistan. Questions were presented bilingually in English and Dari. Prior to the administration of 
the questionnaire, local experts validated its content and the questionnaire was pilot tested. The respondents were informed that their participation was voluntary and consent was implied through their completion of the questionnaire. From June 15th to 19th, the questionnaires were distributed to all 219 members of AECA who were founders of private educational institutions in Afghanistan.

\section{Instruments}

The survey form contained 10 questions that were created and arranged by lecturers of Kabul University of Medical Sciences (KUMS). In this survey form, the first three questions addressed demographic data of the participants; age (under 40 and equal or above 40), sex (male or female) and location (Kabul and other provinces). The demographic questions were to confirm that the participants were, in fact, founders of a private educational institution.

The remaining questions included the respondents' awareness regarding COVID-19, any COVID-19 close contacts, the lease of their institution, government or non-governmental support for their institution, the implementation of online teaching, attainment of students' fees payment and the institutions' financial damages.

\section{Ethical Considerations}

This study was approved by the Research Ethics Committee of Microbiology Department of Kabul University of Medical Sciences (KUMS). Approval code: KUMS/ RECMD - 87.

\section{Statistical Analysis}

The sample size was not determined on the basis of statistical power calculations; however, a sample size of 100 participants (a little less than 50\%) was estimated to be enough based on total AECA members (219 members) who were founders of private educational institutions in Afghanistan. The distribution of categorical variables was described by frequencies and percentages.

\section{Results}

\section{Demographic Characteristics}

Due to limited internet access out of the 219 founders only 105 participants filled the form completely without any valid reason given for the non-responders. According to Table 1, majority of participants (98\%) were male, most of them $(82 \%)$ were aged under 40 years and $18 \%$ of respondents were aged equal/above 40 years and the majority were from Kabul (84\%). (Table 1)
Table I Demographic Characteristics of Educational Centers Owners in Afghanistan [N=105]

\begin{tabular}{|l|c|c|}
\hline Characteristics & Category & n (\%) \\
\hline Gender & Female & $2(2 \%)$ \\
& Male & $103(98 \%)$ \\
\hline Age & $<40$ & $86(82 \%)$ \\
& $\geq 40$ & $19(18 \%)$ \\
\hline Location & Kabul & $88(84 \%)$ \\
& Other provinces & $17(16 \%)$ \\
\hline
\end{tabular}

\section{Perception and Exposure Regarding COVID-19}

Regarding the awareness of COVID-19, this was acquired by $51 \%$ through social media, $31 \%$ through Television, $11 \%$ through their families, neighbors, and friends, 5\% through newspapers and magazines, and $2 \%$ through other resources. (Figure 1)

In accordance with Figures 2, 56\% of the respondents confirmed that they got infected by COVID-19.

\section{Functional and Financial State of Private Educational Centers During the Lockdown Period (March to July 2020)}

In response to the question of whether or not they were pursuing lessons online or not, the majority of the owners (87\%) responded not to conduct online classes, and only $13 \%$ were pursuing online classes. Regarding students' fees payment, $98 \%$ responded that they did not get any kind of payment from students while $2 \%$ received payment from their students. $95 \%$ of the owners asserted that their buildings' rent was paid and 5\% said they did not pay their rent. (Figure 3)

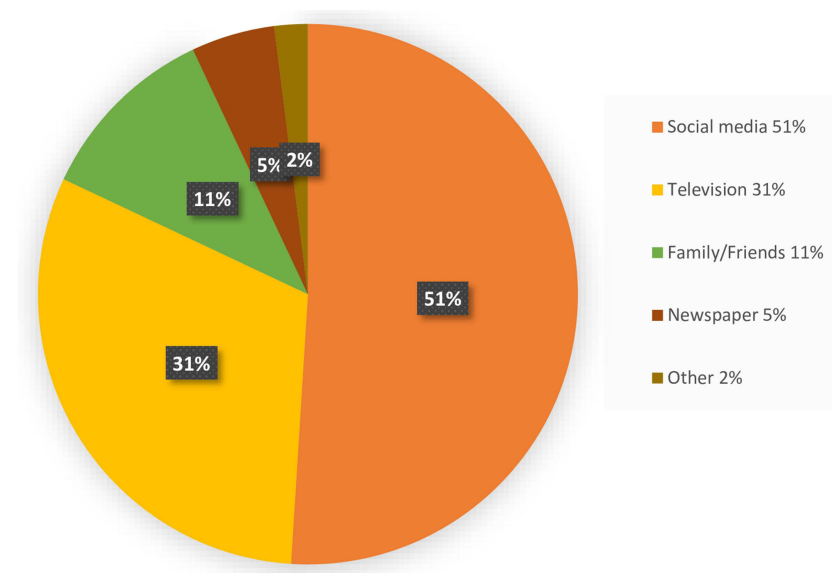

Figure I Method of awareness for COVID-19 by our respondents [N=105]. 


\section{Did you or one of your staff get infected by COVID-19?}

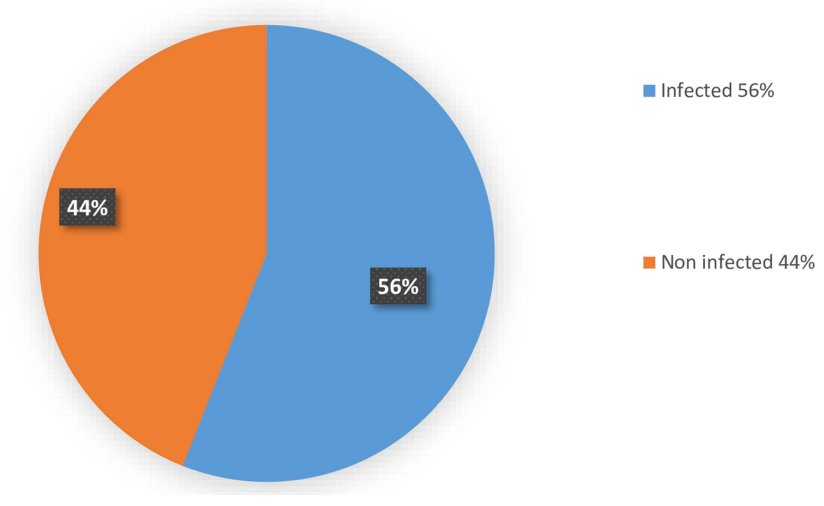

Figure 2 Infection of the private educational centers employees by COVID-19 $[\mathrm{N}=105]$.

Regarding financial damage they encountered, 47\% informed about a loss of 2000-5000\$, 22\% reported a loss of more than $15000 \$, 16 \%$ a loss of $10000-15000 \$, 11 \%$ a loss of less than $2000 \$$ and, and $4 \%$ reported a loss of 5000-10000\$. (Table 2) 100\% of participants reported not to receive any financial support from the government of Afghanistan or from international organizations.

\section{Discussion}

Currently, Afghanistan's education system is formally being managed by three separate entities, the Ministry of Education, the Ministry of Higher Education (MoHE) and religious institutions. In addition to the formal education sector, various national and international non-government
Table 2 Financial Damage of Educational Centers During the Quarantine in Afghanistan [N=105]

\begin{tabular}{|l|c|}
\hline Amount USD & n (\%) \\
\hline $2000 \$$ & $11(11 \%)$ \\
$2000 \$-5000 \$$ & $49(47 \%)$ \\
$5000 \$-10,000 \$$ & $5(4 \%)$ \\
$10,000 \$-15,000 \$$ & $17(16 \%)$ \\
$>15,000 \$$ & $23(22 \%)$ \\
\hline
\end{tabular}

organizations (NGOs) have established education systems throughout the country. While these education are officially under the authority of the central government, these alternative approaches of delivering education to youth in Afghanistan continue to operate independently and allow for the addressing of some of the gaps in the current system. ${ }^{17}$ The unknown number and size of private educational centers, are non-governmental organizations established by individuals without financial relationship with international and national supporters. These institutions are operating in small infrastructures (Apartments of houses amid the communities) with few staff, therefore they are more vulnerable than other institutions when hit by COVID-19 lockdown or any other unexpected conditions.

The results show that the founders are predominantly male and of the younger generation. In a country that has long battled gender discrimination in the case of education, the low rate of females in leadership may be seen as a problem. ${ }^{18}$ The promotion and protection of education depends on that of human rights as well. ${ }^{19}$ As for most of

\section{Functional and Financial state of Private Educational centers during the qurantine}

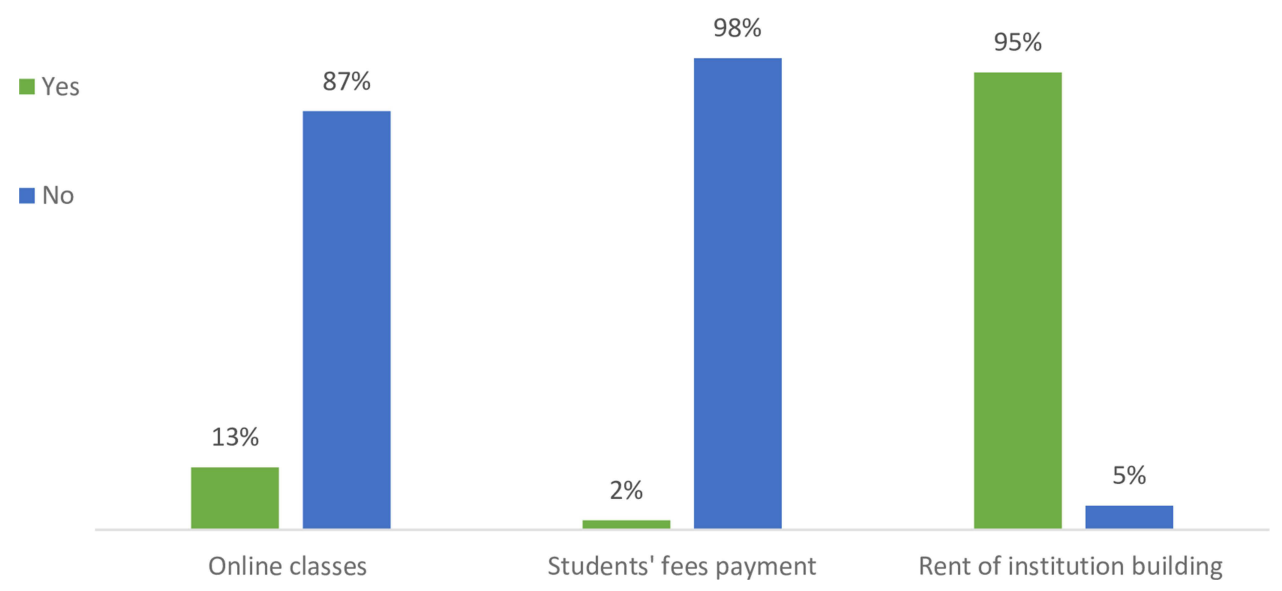

Figure 3 Functional and Financial state of Educational centers [ $\mathrm{N}=105]$. 
the young founders, research regarding the issues and challenges experienced by them is going on. ${ }^{20}$ On the one hand, some studies show that they may only prosper with additional mentorship from consulting agencies. ${ }^{21,22}$

In Afghanistan, based on a survey conducted by the ministry of public health, at least 10 million Afghans have been infected by coronavirus. ${ }^{23}$ It can be realistic that our participants were at high risk of infection.

The sources of COVID-19-related information in Afghanistan are not reliable and very likely spread misinformation across the globe. ${ }^{24}$ They interfere negatively with the founders' public response concerning the COVID-19 prevention measures and the means to regulate the infection rate. ${ }^{25}$ This is further shown by the next question, which discusses the infection exposure amongst the founders themselves and their employees. The response to this was inauspicious with more than half of the participants selecting confirming that they and their employees were infected with the SARS-CoV-2 virus. Hence, it is a major health risks for the entirety of Afghanistan as infection rates are rising uncontrollably.

The President of Afghanistan and the mandate of the Ministry of Education had designed a strategic COVID-19 education response plan that consisted of Information and Communication Technology (ICT) and TV distant learning, self-directed learning, and small group face to face instructed learning. The first two strategies are more problematic than meets the eye as many students and families are too poor to pay internet connections as well as technological devices, and to acquire technological training to operate them. ${ }^{26}$ Along with these technical issues, the electricity in Afghanistan is a recurring serious problem. Taliban and other opposition groups destroy energy resources thus causing days-long blackouts. ${ }^{27}$ This is a great challenge to students' learning sessions to be conducted efficiently. Unfortunately, very few studies have been conducted about Afghanistan during the pandemic of COVID-19. ${ }^{28}$ The authors of this study may be biased to some extent regarding the data analysis as they themselves are founders of a university. However, without them it would not have been possible to collect first-hand experience.

The greatest impact that COVID-19 had in Afghanistan was that on the education system, the overall economic status, and the healthcare system. From a financial perspective, the private education centers are fragile and dependent on the students' fees payment. Therefore they are bound to be confronted with huge challenges, which may lead to the breakdown and discontinuation of these centers. $^{29}$ The lockdown measures were strict on the ban of public gatherings, social activities and all educational centers such as universities and schools. Consequently, the authors of this paper conducted an unbiased assessment to survey the impact of the lockdown measures on educational centers and to highlight their problems. From a large number of educational centers that were invited to take part in the survey, the harm caused as noted by the participants is drastic. They are mainly related to the fact that only $2 \%$ of their students paid the required fees. The study participants declared that each of their educational institutions experienced a financial loss between 2000-10000\$. Even more, although the government of Afghanistan provided a budget to support private institutions, none of the founders received anything from a governmental no an international donor organization for their institutions that had financial losses during the quarantine period. This proves the severe negligence of internal and external donors vis-à-vis private educational centers. And the financial loss of these centers is irreparable. Taking the financial loss aside, education was halted in $87 \%$ of the private educational organizations. You have said this above. This demonstrates the depth of the COVID-19 pandemic health tragedy in Afghanistan. The public health response has been inadequately instructed thus they are not being taken seriously and infection rates are skyrocketing.

\section{Limitations}

The study questionnaire was first created and did not find any similar published studies to enrich its content. However, content validation was performed to increase the reliability of the results. Participants were asked specific questions that might not cover all issues involved in the health and financial status of private educational institutions. Lastly, as the participants were the owners of institutions, they might have expressed an exaggerated financial loss. This would decrease the credibility of the results.

\section{Strength}

This study highlights the difficult condition faced by private educational centers amid COVID-19 pandemic. During this challenging time, the private educational centers were operating with minimal support from the government. The study calls on all organizations and people outside Afghanistan for investment in the educational sector, the one hit hard by the pandemic. Moreover, the study shows there is an intense lack of women in leading private educational institutions, which is very important for women's leadership and country's development. 


\section{Recommendations}

The COVID-19 almost devastated Afghanistan's health and education system with private educational institutions being no exception. Based on our findings the private educational centers require great attention regarding their financial needs, education technology, and related investments so as to ensure continuity of educations for Kankor preparation students and English learners. In short the following items we recommend:

- Supportive funding needs to be approved by government and donors for the centers that had massive financial losses during the lockdown period to prevent the permanent closure of them.

- Private educational centers' leaders need to work closely with the governmental health authorities to prioritize their staff for COVID-19 vaccination.

\section{Conclusion}

Afghanistan's private education centers encountered serious financial and health challenges during the COVID-19 pandemic. The survey results show that founders of educational institutions complained about a large financial loss due to the lack of fees paid by their students. Along with that, lack of support from the government and other internal and external charitable organizations were a problem. Classes have been discontinued in $87 \%$ of the private schools and universities thus declining the education progress in Afghanistan. Along with these consequences from COVID-19, Afghanistan already suffers from poor economic status in families and cannot afford sufficient internet connections plus telecommunication devices. Considering the low national level of education in Afghanistan, many families do not have the technical education to operate these devices. The COVID-19 education repercussions together with the former education issues in Afghanistan have led to a crisis for all students that requires significant attention towards all nongovernmental organizations.

\section{Data Sharing Statement}

To ensure confidentiality of the participants and observe relevant ethical considerations, data cannot be shared publicly. However, data can be accessed upon request from Prof Dr Ahmad Wali Atayee, Head of Department of Microbiology, Kabul University of Medical Sciences via email: drataye1@gmail.com.

\section{Ethical Approval and Consent}

The study was conducted in accordance with the Declaration of Helsinki. All participants agreed to participate before filling the questionnaire. The research project was approved by the research ethical committee at Microbiology department of Kabul University of Medical Sciences.

\section{Consent for Publication}

Not applicable.

\section{Acknowledgments}

The authors would like to sincerely thank PD Dr. Silvia Kaeppeli for helping to edit this manuscript.

\section{Author Contributions}

All authors made significant contribution to the work reported, either in the conception, study design, execution, acquisition of data, analysis and interpretation, or in all these areas; took part in drafting, revising or critically reviewing the article; have agreed on the journal to which the article has been submitted; and agree to be accountable for all aspects of the work. All authors attest they meet the ICMJE criteria for authorship.

\section{Funding}

This research did not receive any specific grant from funding agencies in the public, commercial, or not-forprofit sectors.

\section{Disclosure}

The authors declare no conflicts of interest for this work and that they have no known competing financial interests or personal relationships that could have appeared to influence the work reported in this paper.

\section{References}

1. Farah K, Fauzee O, Daud Y. Teacher training education programme in three Muslim Countries-Afghanistan, Iran and Pakistan. J Edu Human Develop. 2014;3:729-741.

2. Khwajamir M, Çalişkan H, Önder I, Masal E, Beşoluk Ş. History and Problems of Education in Afghanistan. SHS Web Conf. 2016;26:01124. doi:10.1051/shsconf $/ 20162601124$

3. Anadulo Agency A-P. Latest on coronavirus outbreak., COVID-19: afghanistan finally reopens all schools; 2020. Available from: https:// www.aa.com.tr/en/asia-pacific/covid-19-afghanistan-finally-reopensall-schools/1994551\#. Accessed June 25, 2021.

4. UNICEF Afghanistan. Education; Providing quality education for all. Available from: https://www.unicef.org/afghanistan/education. Accessed June 25, 2021. 
5. World Education News + Reviews. Education in Afghanistan; 2016. Available from: https://wenr.wes.org/2016/09/education-afghanistan. Accessed June 25, 2021.

6. Islamic Republic of Afghanistan. Afghan Constitution. Available from: https://president.gov.af/en/afghan-constitution-2/. Accessed June 25, 2021.

7. Bamik H. Restructuring the Kankor Examination Format; A Feasible Solution for the Existing Issues with the Current Kankor Examination in Afghanistan. Humanitarian SocioEconomic Sci J. 2019;12-29.

8. Sediqi F. A sociolinguistic profile of English in Afghanistan: the perspectives of Kabul academics. Purdue University; 2010.

9. Miri MA. The impact of the English language in Afghanistan: an autoethnography. Int J TESOL Learning. 2019;8:1-14.

10. Afghanistan's learning crisis: how bad is it really?. Available from: https://blogs.worldbank.org/endpovertyinsouthasia/afghanistans-learning-crisis-how-bad-it-really. Accessed June 25, 2021.

11. Roof DJ. In FIRE: forum for International Research in Education. 64-80 (ERIC).

12. TOLO NEWS. Covid-19 Measures Are Crippling Afghan Education. Available from: https://tolonews.com/opinion/covid-19-measures-are -crippling-afghan-education. Accessed June 25, 2021.

13. University World News. Universities are the key to pandemic recovery; 2020. Available from: https://www.universityworldnews. com/post.php?story=20200707083611676. Accessed June 25, 2021.

14. Ariana News. Survey finds at least 10 million Afghans infected with COVID-19; 2020. Available from: https://ariananews.af/survey-findsat-least-10-million-afghans-infected-with-covid-19/. Accessed June $25,2021$.

15. TOLO NEWS. 150 Herat Students Test Positive for COVID-19 in Past Week; 2020. Available from: https://tolonews.com/afghanistan167023. Accessed June 25, 2021.

16. Cousins S. Afghanistan braced for second wave of COVID-19. Lancet. 2020;396:1716-1717. doi:10.1016/S0140-6736(20)32529-0

17. UNICEF. Global initiative on out-of-school children. Available from: https:/www.unicef.org/afghanistan/sites/unicef.org.afghanistan/files/ 2018-05/afg-report-oocs2018.pdf. Accessed June 25, 2021.

18. Shayan Z. Gender inequality in education in Afghanistan: access and barriers. Open J Philosophy. 2015;5:277. doi:10.4236/ojpp.2015. 55035
19. Iacopino V, Rasekh Z. Education, a health imperative: the case of Afghanistan. Health Hum Rights. 1998;98-108. doi:10.2307/4065302

20. Ridzwan R, Muhammad NMN, Rahman A. Issues and challenges among young entrepreneurs in Malaysia. IOSR J Business Manage. 2017;19:80-84. doi:10.9790/487X-1903028084

21. Lorrain J, Laferté S. Support Needs of the Young Entrepreneur. J Small Business Entrepreneurship. 2006;19:37-48. doi:10.1080/ 08276331.2006 .10593357

22. Frank AI. Entrepreneurship and enterprise skills: a missing element of planning education? Planning, Practice Res. 2007;22:635-648. doi:10.1080/02697450701770142

23. Ariana News. Survey finds at least 10 million Afghans infected with COVID-19. Available from: https://ariananews.af/survey-finds-atleast-10-million-afghans-infected-with-covid-19/. Accessed June 25, 2021.

24. Gottlieb M, Dyer S. Information and Disinformation: social Media in the COVID-19 Crisis. Acad Emergency Med. 2020;27:640-641. doi:10.1111/acem.14036

25. Barua Z, Barua S, Aktar S, Kabir N, Li M. Effects of misinformation on COVID-19 individual responses and recommendations for resilience of disastrous consequences of misinformation. Progress Disaster Sci. 2020;8:100119. doi:10.1016/j.pdisas.2020.100119

26. Pajhok Afghan news. The Challenges of Remote Learning in Afghanistan. Available from: https://pajhwok.com/2020/06/11/thechallenges-of-remote-learning-in-afghanistan/. Accessed June 25, 2021.

27. The national opinion. Why blackouts are so common in Afghanistan. Available from: https:/www.thenationalnews.com/opinion/comment/ why-blackouts-are-so-common-in-afghanistan-1.1024905. Accessed June 25, 2021.

28. Mousavi SH. Mapping the Changes on Incidence, Case Fatality Rates and Recovery Proportion of COVID-19 in Afghanistan Using Geographical Information Systems. Arch Med Res. 2020. doi:10.1016/j.arcmed.2020.06.010

29. United Nations Educational, S. a. C. O. Education and fragility in Afghanistan. Available from: https://reliefweb.int/sites/reliefweb.int/ files/resources/23625C51EB5B372949257603001DCB4EFull_Report.pdf. Accessed June 25, 2021.
Journal of Multidisciplinary Healthcare

\section{Publish your work in this journal}

The Journal of Multidisciplinary Healthcare is an international, peerreviewed open-access journal that aims to represent and publish research in healthcare areas delivered by practitioners of different disciplines. This includes studies and reviews conducted by multidisciplinary teams as well as research which evaluates the results or conduct of such teams or healthcare processes in general. The journal covers a very wide range of areas and welcomes submissions from practitioners at all levels, from all over the world. The manuscript management system is completely online and includes a very quick and fair peer-review system. Visit http://www.dovepress.com/testimonials. php to read real quotes from published authors. 